\title{
RHIZOME AND ROOT ANATOMY OF 14 SPECIES OF BROMELIACEAE ${ }^{1}$
}

\author{
Suzana Lúcia Proença $a^{2,3,4}$ \& Maria das Graças Sajo ${ }^{2,3}$
}

\begin{abstract}
(Rhizome and root anatomy of 14 species of Bromeliaceae) The anatomy of rhizomes and roots of 14 species of Bromeliaceae that occur in the cerrado biome were studied with the aim of pointing out particular anatomical features of the family and possible adaptations related to the environment. All the rhizomes are similar although some have root regions growing inside the cortex. In some species the vascular cylinder of the rhizome is clearly limited from the cortex. The roots are also very similar, although the coating tissue differs in roots growing inside the rhizome or externally to it and the cortex has a variable organization according to the region. The studied species present anatomical features that are associated to water absorption and storage, showing that they are adapted to the cerrado environment.
\end{abstract}

Key words: bromeliads, Pitcairnioideae, Bromelioideae, Tillandsioideae, water capture, water retention, 'cerrado'.

Resumo

(Anatomia de raízes e rizomas de 14 espécies de Bromeliaceae) Com o objetivo de reconhecer caracteres particulares de Bromeliaceae e indicar possíveis formas de adaptação ao ambiente, foi estudada a anatomia dos rizomas e raízes de 14 espécies de Bromeliaceae que ocorrem no cerrado. Os rizomas apresentam estrutura básica semelhante, embora alguns deles possuam porções radiculares crescendo no interior de seu córtex. De acordo com a espécie considerada, os rizomas podem apresentar um cilindro vascular de delimitação mais ou menos nítida. As raízes também possuem estrutura básica semelhante, apesar do tecido de revestimento variar de acordo com a porção analisada (dentro do rizoma ou externa). Além disso, as raízes apresentam uma região cortical de organização variada, de acordo com a região do órgão, e um cilindro vascular. Muitos dos caracteres anatômicos observados estão associados a mecanismos de captação e retenção hídrica, mostrando que as espécies estudadas estão adaptadas ao ambiente de cerrado.

Palavras-chave: bromélias, Pitcairnioideae, Bromelioideae, Tillandsioideae, captura de água, retenção hídrica, cerrado.

\section{INTRODUCTION}

Bromeliaceae is included in the order Poales (APG II 2003) and comprises 56 genera and around 3000 species (Luther 2002) that, except for Pitcairnia feliciana (A. Chev.) Harms \& Mildbr. from the West Africa, occupy various habitats in the tropical and subtropical regions of the New World (Pittendrigh 1948).

The plants are mostly herbaceous with a reduced stem from where leaves, inflorescences and lateral shoots originate.
Bromeliaceae has traditionally been divided in three subfamilies: Pitcairnioideae, Tillandsioideae and Bromelioideae (Smith \& Downs 1974, 1977, 1979; Dahlgren et al. 1985), although recent phylogenetic analyses do not confirm the monophyly of Pitcairnioideae (Crayn et al. 2000; Horres et al. 2000). The subfamilies are separated according to the growth habit, the fruit and seed morphology and the ovary position (Smith \& Downs 1974, 1977, 1979). Bromelioideae are generally terrestrial and

\footnotetext{
Artigo recebido em 06/2007. Aceito para publicação em 01/2008.

${ }^{1}$ Part of the PhD thesis of the first author, Universidade Estadual Paulista, Campus de Rio Claro.

${ }^{2}$ Universidade Estadual Paulista, Instituto de Biociências, Departamento de Botânica, C.P. 199, 13506-900, Rio Claro, SP, Brasil.

${ }^{3} \mathrm{CNPq}$ fellowship; financial support by FAPESP

${ }^{4}$ Author for correspondence: suzanaproenca@ hotmail.com
} 
epiphytic and their leaf sheaths are usually wide and imbricate forming tanks where the water and minerals accumulate to be absorbed by scales and by the adventitious roots growing there (Benzing \& Burt 1970, Benzing 2000). In the terrestrial species without tanks, as some Bromelia and Ananas, the roots absorb water and nutrients directly from the soil (Benzing et al. 1976). Most Tillandsioideae are epiphytes and have a reduced or absent root system and specialized scales covering the leaves; in these plants called "atmospheric or extreme" the scales help in the hydric and nutritional balance; the roots, when present, are mainly involved in fixation (Benzing \& Burt 1970; Benzing 1973). Pitcairnioideae are usually terrestrial and rupicolous and grow in mesic and xeric habitats; they present a well developed root system for fixation and water and nutrient absorption. The leaf scales in this subfamily are less developed and have little or no water absorption function (Pittendrigh 1948, Benzing \& Burt 1970, Benzing et al. 1976).

The rhizomes of Bromeliaceae are not well known although Billings (1904) had described the rhizome of Tillandsia usneoides L. and Krauss (1948) had carefully studied the morphology and the anatomy of the rhizome of Ananas comosus (L.) Merr. Later, Segecin and Scatena (2004) described the rhizomes of some Tillandsia and interpreted them as a possible adaptation to the epiphytic habit.

The stems of monocot do not present a cambium but many species posses a lateral apical meristem that determines the shape of the plant. This meristem, called primary thickening meristem, is responsible for thickening of the stem and for the formation of the adventitious roots and of the vascular connection among the stem, roots and leaves. In some monocot genera, a secondary thickening meristem is also present, which contributes to the formation of the stem body (Rudall 1991).
As for the rhizomes, studies on the root anatomy of Bromeliaceae are rare. Krauss (1949), Pita \& Menezes (2002) and Segecin $\&$ Scatena (2004) related the rhizome anatomy of the species they studied to the growth habit of the plants and/or to the environment where they grow.

The present study describes the morpho-anatomy of the rhizomes and roots of epiphytic and terrestrial bromeliads from the cerrado of São Paulo State, with the aim of pointing out particular features of the Bromeliaceae as well as possible adaptive features found in the cerrado vegetation.

\section{Material and Methods}

The material was collected in areas of cerrado in São Paulo State, Brazil and identified by the first author. Vouchers are deposited at the Rioclarense Herbarium (HRCB) of the State University of São Paulo (Table 1).

For the anatomical study at least two representatives of each species were used. Roots and rhizomes were fixed in FAA 50 (Johansen 1940) for 48h and later preserved in ethanol $50 \%$. Cross sections were made by free hand in the apical and median regions of both organs. The sections were stained with Safranin and Astra blue (Bukatsch 1972 modified by Kraus \& Arduin $1997)$ and mounted in glycerin gelatin Kaiser (1880). For Tillandsia usneoides only the stem was studied since this species does not present roots when adult.

Sections of fresh material were used to test the presence/absence of phenolic compounds (Johansen 1940), starch (Johansen 1940), lignin (Sass 1951), lipids (Gerlach 1984) and to determine the crystals chemical nature (Chamberlain 1932).

The photomicrographs were taken using an Olympus BX40 photomicroscope and a Leica MZ12 stereomicroscope. 
Table 1 - List of studied species

\begin{tabular}{|c|c|c|c|}
\hline Subfamilies/Species & Life forms & Place of collect & Voucher \\
\hline \multicolumn{4}{|l|}{ BROMELIOIDEAE } \\
\hline $\begin{array}{l}\text { Acanthostachys strobilacea } \\
\text { (Baker) L.B.Sm. }\end{array}$ & Epiphyte & $\begin{array}{l}\text { Reserva Biológica } \\
\text { de Moji-Guaçu }\end{array}$ & S. L. Proença 201 \\
\hline Aechmea bromeliifolia (Rudge) Baker & Epiphyte & $\begin{array}{l}\text { Área de Proteção } \\
\text { Ambiental de Corumbataí }\end{array}$ & S. L. Proença 212 \\
\hline Ananas ananassoides (Baker) L.B.Sm. & Terrestrial & $\begin{array}{l}\text { Estação Experimental } \\
\text { de Itirapina }\end{array}$ & S. L. Proença 192 \\
\hline Billbergia distachia (Vell.) Mez & Epiphyte & $\begin{array}{l}\text { Reserva Biológica } \\
\text { de Moji-Guaçu }\end{array}$ & S. L. Proença 208 \\
\hline Billbergia porteana Brongn. & Epiphyte & $\begin{array}{l}\text { Reserva Biológica } \\
\text { de Moji-Guaçu }\end{array}$ & S. L. Proença 198 \\
\hline Bromelia balansae $\mathrm{Mez}$ & Terrestrial & $\begin{array}{l}\text { Estação Experimental } \\
\text { de Itirapina }\end{array}$ & S. L. Proença 197 \\
\hline \multicolumn{4}{|l|}{ PITCAIRNIOIDEAE } \\
\hline Dyckia tuberosa (Vell.) Beer & Terrestrial & $\begin{array}{l}\text { Universidade de } \\
\text { São Paulo (USP), Pirassununga }\end{array}$ & S. L. Proença 213 \\
\hline \multicolumn{4}{|l|}{ TILLANDSIOIDEAE } \\
\hline $\begin{array}{l}\text { Tillandsia loliacea Mart. } \\
\text { ex Schult. \& Schult. f. }\end{array}$ & Epiphyte & $\begin{array}{l}\text { Área de Proteção } \\
\text { Ambiental de Corumbataí }\end{array}$ & S. L. Proença 202 \\
\hline Tillandsia pohliana $\mathrm{Mez}$ & Epiphyte & $\begin{array}{l}\text { Reserva Biológica } \\
\text { de Moji-GuaçuPratânia }\end{array}$ & $\begin{array}{l}\text { S. L. Proença } 186 \\
\text { S. L. Proença } 216\end{array}$ \\
\hline Tillandsia recurvata (L.) L. & Epiphyte & $\begin{array}{l}\text { Estação Experimental de } \\
\text { ItirapinaReserva Biológica } \\
\text { de Moji-GuaçuPratânia }\end{array}$ & $\begin{array}{l}\text { S. L. Proença } 194 \\
\text { S. L. Proença } 209 \\
\text { S. L. Proença } 215\end{array}$ \\
\hline Tillandsia tenuifolia $\mathrm{L}$. & Epiphyte & $\begin{array}{l}\text { Reserva Biológica } \\
\text { de Moji-Guaçu }\end{array}$ & S. L. Proença 210 \\
\hline Tillandsia tricholepis Baker & Epiphyte & $\begin{array}{l}\text { Estação Experimental de } \\
\text { ItirapinaÁrea de Proteção } \\
\text { Ambiental de Corumbataí }\end{array}$ & $\begin{array}{l}\text { S. L. Proença } 195 \\
\text { S. L. Proença } 204\end{array}$ \\
\hline Tillandsia usneoides (L.) L. & Epiphyte & Estação Experimental de Itirapina & S. L. Proença 193 \\
\hline Vriesea $\mathrm{sp}$. & Epiphyte & Estação Experimental de Itirapina & S. L. Proença 217 \\
\hline
\end{tabular}




\section{Results}

Rhizome

Most of the studied species are epiphytic, except for the terrestrial Ananas ananassoides, Dyckia tuberosa and Bromelia balansae. The rhizomes are vertically or horizontally positioned with their apical portion pointing upward. In the median and basal regions of all rhizomes, axillary buds develop and originate new rhizomes that, in the case of Bromelia balansae, are fairly long and covered by reduced, scale-like leaves. In Acanthostachys strobilacea, the rhizome supports few green leaves and its base presents reduced cataphylls as those found in the stolons of Bromelia balansae.

Independently of their morphology, all rhizomes are anatomically very similar in structure and present three regions: a coat, consisting of the epidermis and/or a stratified layer of cork (Figs. 1a, c-f), a cortex (Figs. 1a, b, f; 2a-c) and a vascular cylinder (Figs. 1a, b, f; 2a-c). Starch grains (Figs. 1a; 2b) and idioblasts of calcium oxalate raphides (Figs. 1a, b; 2c) are common in the cortex and in the vascular cylinder. In Billbergia porteana, Bromelia balansae and D. tuberosa, mucilage canals are also observed in the rhizome cortex (Figs. 1f, 2a).

When present, the epidermis is onelayered and its cells, often with silica bodies, vary in size and shape (Figs. 1a, c, d). The epidermal cells have thin walls in the rhizomes of most Tillandsioideae (Tillandsia recurvata (Fig. 1a), T. usneoides, T. tricholepis, T. loliacea and Vriesea sp.) and thick, lignified walls in the rhizomes of the Tillandsioideae $T$. tenuifolia (Fig. 1c) and in the Bromelioideae Aechmea bromeliifolia (Fig. 1d). In the latter species there is also a stratified cork layer internal to the epidermis. In the Bromelioideae Acanthostachys strobilacea, and in the Tillandsioideae $T$. pohliana, the rhizome is covered with various layers of sclerified cells and with an internal stratified cork. In the rhizome of the other Bromelioideae (Billbergia distachia (Fig. 1e), B. porteana (Fig. 1f),
Ananas ananassoides and Bromelia balansae) and in the Pitcairnioideae $D$. tuberosa, the coating tissue is a stratified cork.

The cortex, formed by rounded parenchymatous cells of variable sizes, presents leaf traces (Figs. 1a, b, f; 2a-c) axillary buds and besides idioblasts with calcium oxalate raphides (Figs. 1a, b; 2c). The endodermis is recognized by the position of its parenchymatous cells (Figs. 1a; 2a, b), although in Aechmea bromeliifolia there is no a visible delimitation between the cortex and the vascular region (Fig. 2c). The rhizome of all Tillandsia (Fig. 1b) (except T. usneoides) and of the Pitcairnioideae D. tuberosa show many intracortical roots that originate from the pericycle. In these roots the endodermis is one-layered and its cells possess anticlinal thickened walls, in D. tuberosa, and all the walls thickened, in Tillandsia. Figure 1b show intracortical roots in different developmental stages.

Collateral bundles randomly distributed form the vascular system; these bundles can be partially or completely surrounded by sclerified cells (Figs. 1a, b, f; 2a-c). In most of Tillandsioideae (T. recurvata (Fig. 1a), T. tricholepis, T. usneoides and Vriesea sp.), the cortex is separated from the vascular region by a ring of pericycle fibers that include many vascular bundles; this ring is interrupted only by the leaf traces (Fig. 1a). The collateral bundles of the center of the cylinder are surrounded by few sclerified cells (Fig. 1a). In the other Tillandsioideae (T. tenuifolia (Fig. 1b), T. loliacea and T. pohliana), the limit between the cortex and the vascular cylinder is recognized only by the proximity of the peripheral bundles (Fig. 1b). In these species, the collateral bundles of the center of the cylinder are surrounded by sclerified cells (Fig. 1b).

As in most Tillandsioideae (Fig. 1a), the rhizome of most Bromelioideae (Figs. 1f; 2a, b) and that of the Pitcairnioideae D. tuberosa present a ring of pericyclic cells separating the cortical region from the vascular one. In these 

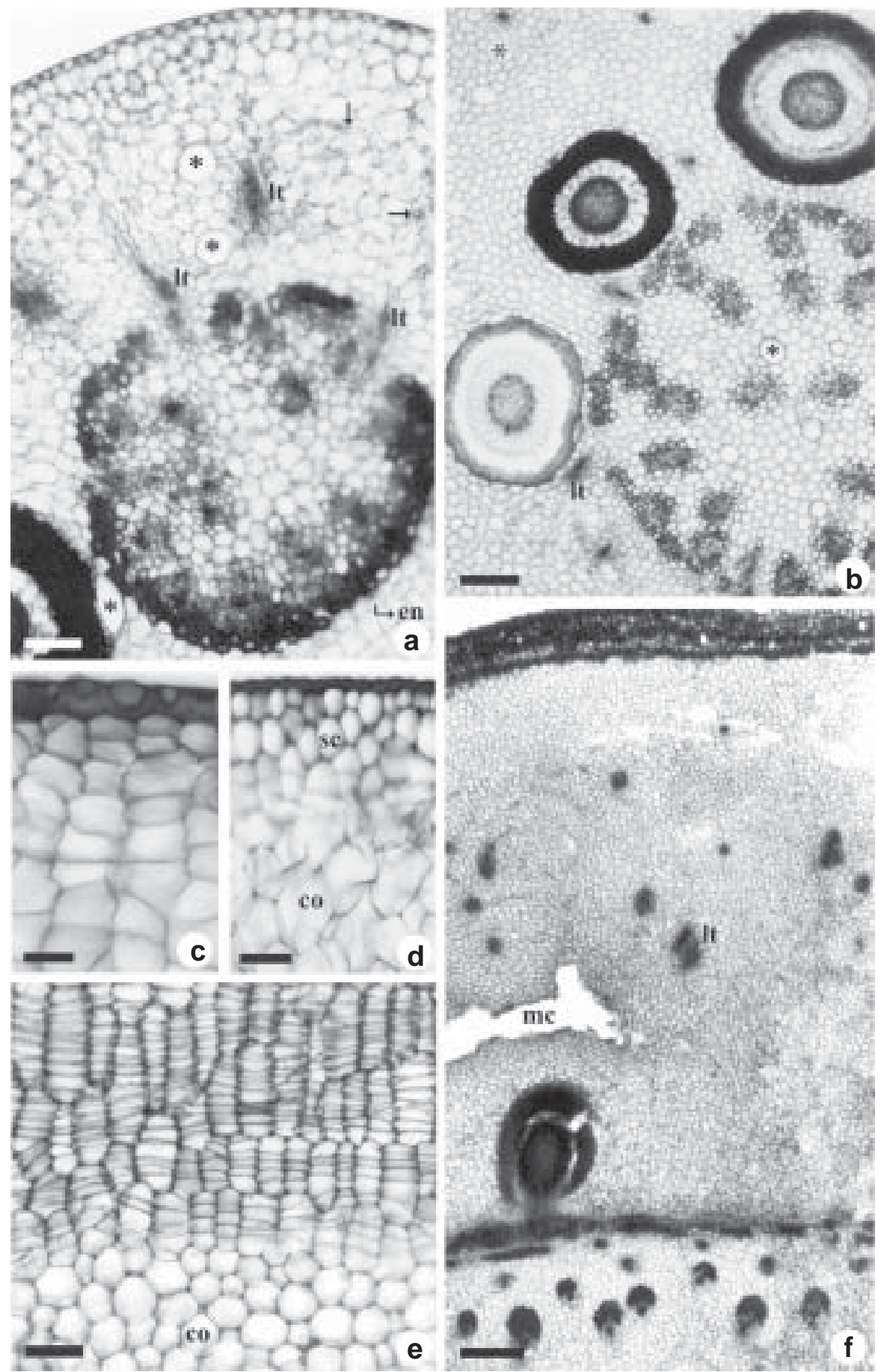

Figure 1 - Cross sections at the median region of the rhizomes. a. Tillandsia recurvata, with a single layer epidermis and an endoderm (en) surrounding the pericycle fibers limiting the vascular region; note starch grains (arrows) and leaf traces (lt) in the cortex. b, c. T. tenuifolia. b. show intracortical roots and peripheral bundles close together on the limit of the central cylinder; note the leaf traces (lt). c. show a lignified epidermis and a stratified inner cork. d. Aechmea bromeliifolia, with a lignified epidermis and a stratified inner cork (sc). e. Billbergia distachia, with a widely stratified cork. f. B. porteana, with stratified cork plus mucilage canal $(\mathrm{mc})$ and leaf trace (lt) in the cortex; note the pericycle fibers limiting the vascular region. Asterisks of the figures $a$ and $b$ show idioblasts of raphides without content. (co = cortex) Bars $=30 \mu \mathrm{m}$ (fig. c); $70 \mu \mathrm{m}$ (fig. a, d, e); $200 \mu \mathrm{m}$ (fig. b); $770 \mu \mathrm{m}$ (fig. f). 

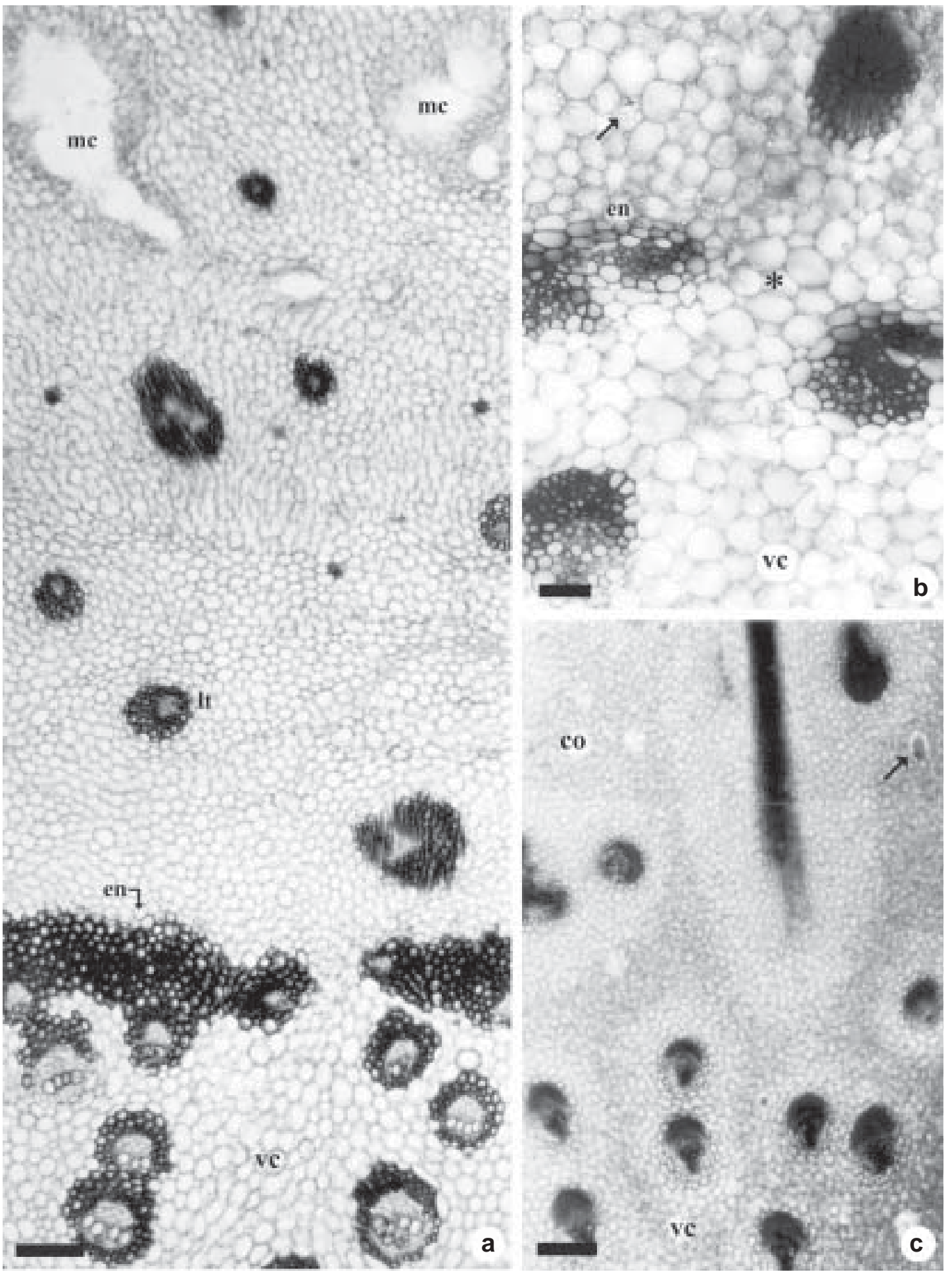

Figure 2 - Cross sections at the median region of the rhizomes. a. Bromelia balansae, with mucilage canals (mc) and leaf trace (lf) in the cortex and a parenchymatous endoderm (en); note the pericycle fibers limiting the vascular cylinder (vc). b. Billbergia distachia, with a parenchymatous endoderm (en); note the leaf gap (asterisk) and starch grains (arrow). c. Aechmea bromeliifolia, lacking a visible limit between the cortex (co) and the vascular cylinder (vc); the arrow show

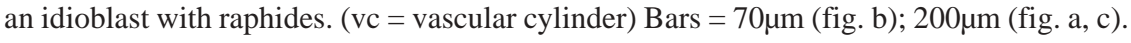


cases too, the ring is only discontinuous in the regions where the leaf traces cross the cylinder (Figs. 1a; 2a, b). However, in opposition to the rhizomes of Tillandsioideae, the vascular bundles adjacent to the pericycle are smaller than those of the central region (Figs. 1f; 2a, b) and are surrounded by sclerified cells particularly at the phloem end (Figs. 1f; 2a, b).

The rhizome of the Bromelioideae Aechmea bromeliifolia does not have a clear boundary between the vascular region and the cortex (Fig. 2c); here the vascular bundles are scattered throughout the central region and there are leaf traces in the cortical portion (Fig. $2 \mathrm{c})$. However, as in the other representatives of this subfamily, the collateral vascular bundles of the rhizome are also surrounded by sclerified cells, especially at the phloem end (Fig. 2c).

\section{Root}

The intracortical roots, observed in the rhizomes of most Tillandsia (Tillandsioideae) and in the Pitcairnioideae Dyckia tuberosa, originate from the pericycle at the apex of the stem. They and run through the cortex basipetally, parallel to the rhizome surface, emerging at the base to fix the plant to the substrate.

In the rhizomes of Bromelioideae, the roots originate from the pericycle at the stem base and grow perpendicularly to the axis. Some roots reach the substrate and fix the plants, while others, still young, nest between the leaf sheaths, where water and nutrients are retained and can be absorbed.

The coating tissue is a multilayered rhizodermis (Figs. 3a-d; 4a-d; 5a, b, d; 6c) except on the intracortical portions that are covered with one layer of rhizodermal cells (Fig. 6b). The cells of the multilayered rhizodermis vary in shape and have thin walls close to the root apex (Figs. 3a-d) and thickened walls in distal regions (Figs. 4a, d; $5 a)$. The outer layer of this tissue bears unicellular hairs on the root apex (Figs. 3c, d) and on all the extension of the roots of Bromelia balansae (Fig. 4a), Aechmea bromeliifolia (Fig. 4b), Ananas ananassoides (Fig. 4d), Acanthostachys strobilacea, Billbergia distachia and D. tuberosa. Under this coat, all the roots show a cortical region and a vascular cylinder (Figs. 3a, b, d; 4b-d; 5a, b, d; 6c).

In the apical and regions, the cortex is parenchymatous (Figs. 3a, b) and its inner layers, close to the endodermis, are arranged in a stratified way (Figs. 3a, b, d; 6a). The endodermis is recognized by the Casparian strips (Figs. 3a, b).

In the sub-apical region, the one or twolayered exodermis is formed by cells of thickened suberized and/or lignified walls (Figs. 3c, d); the passage cells have only primary walls (Fig. 3c). The inner layers of the parenchymatous cortex are larger than the outers and separated by small intracellular spaces (Figs. 3a, b; 6a) that become wider in the distal regions of the root (Figs. 4b-d; 5a-d; 6b, c).

From the sub-apical region on there is a centripetal sclerification on the cell walls of the outer cortex (Figs. 4b, d; 5b; 6b), which, in some cases, extends until the median cortical portion (Figs. 4c; 5d; 6c). The endodermis cell walls are anticlinally thickened in the roots of the Pitcairnioideae D. tuberosa (Fig. 5c) and of all Bromelioideae (Figs. 4c, d) but Bromelia balansae with endodermal cell walls anticlinally and inner periclinally thickened (Figs. 5a, d). In the Tillandsioideae roots, all the endodermis cell walls are thickened (Figs. $5 \mathrm{~b}$; 6a-c). Idioblasts of calcium oxalate raphides occur both in the multilayered rhizodermis (Figs. 4a; 5a) and in the root cortex.

The central cylinder is delimited by a onelayered pericycle formed by thin-walled cells. The xylem is polyarch (Figs. 3a, b; 4b-d; 5a, b; $6 a)$ and the root medulla is usually parenchymatous close to the apex (Figs. 3a, d) becoming distally lignified (Figs. 4b, c; 5d; $6 a-c)$. The lateral roots have the same anatomical organization, but with fewer cell layers in the cortex and fewer vascular tissues in the central cylinder (Fig. 5d). 

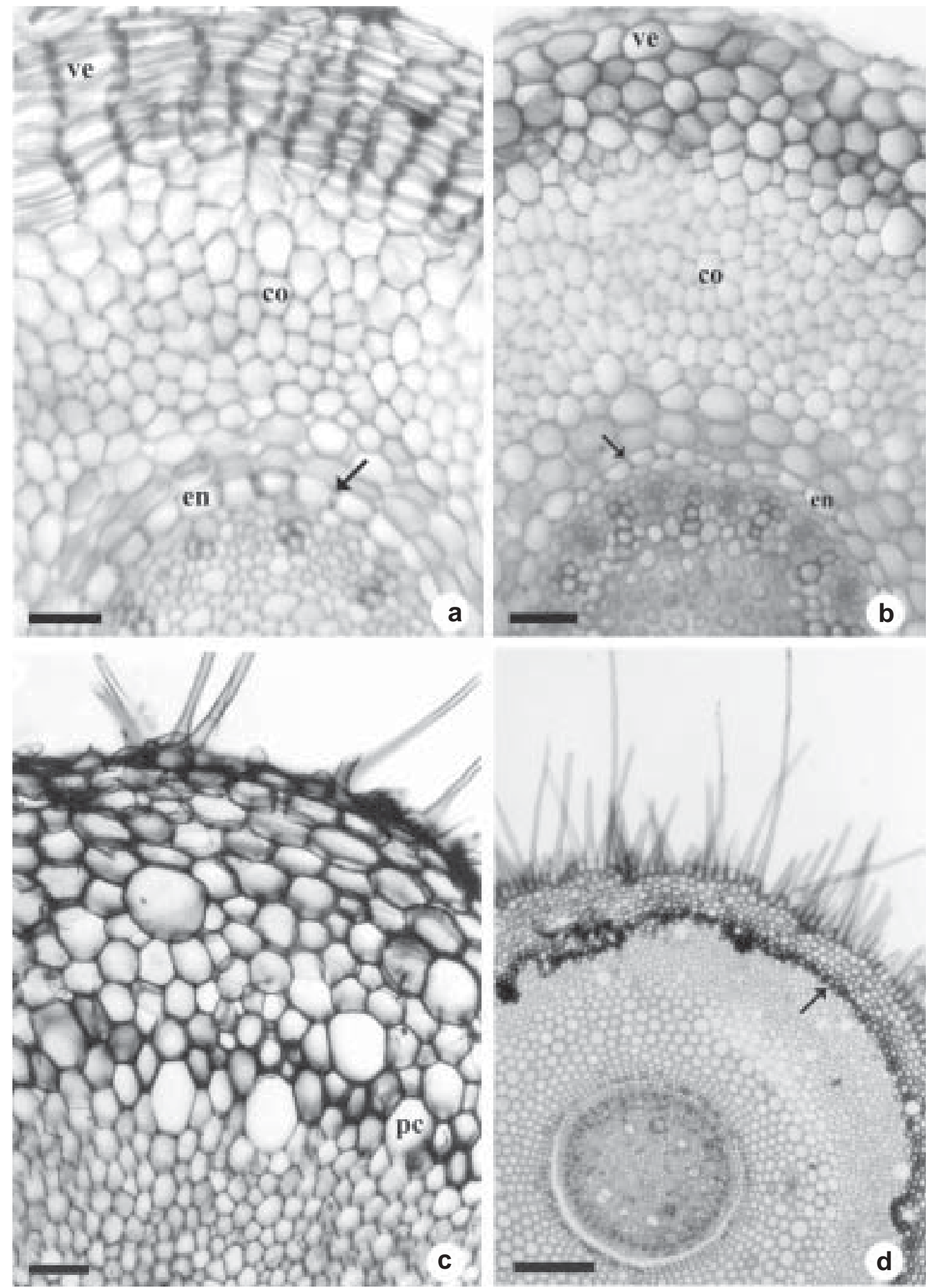

Figure 3 - Cross sections of roots. a, b. apex with velamen (ve), parenchymatous cortex (co) and endoderm (en) with Casparian strips in its cells (arrow). a. Billbergia distachia. b. Tillandsia tenuifolia. c, d. sub-apical region showing epivelamen with unicellular hairs and 1-2 layered exodermis of cells with suberized and/or lignified walls. c. Dyckia tuberosa. d. Bromelia balansae, the arrow indicates the exodermis. $(\mathrm{pc}=$ passage cell). Bars $=30 \mu \mathrm{m}$ (fig. a, b, c); $200 \mu \mathrm{m}$ (fig. d). 

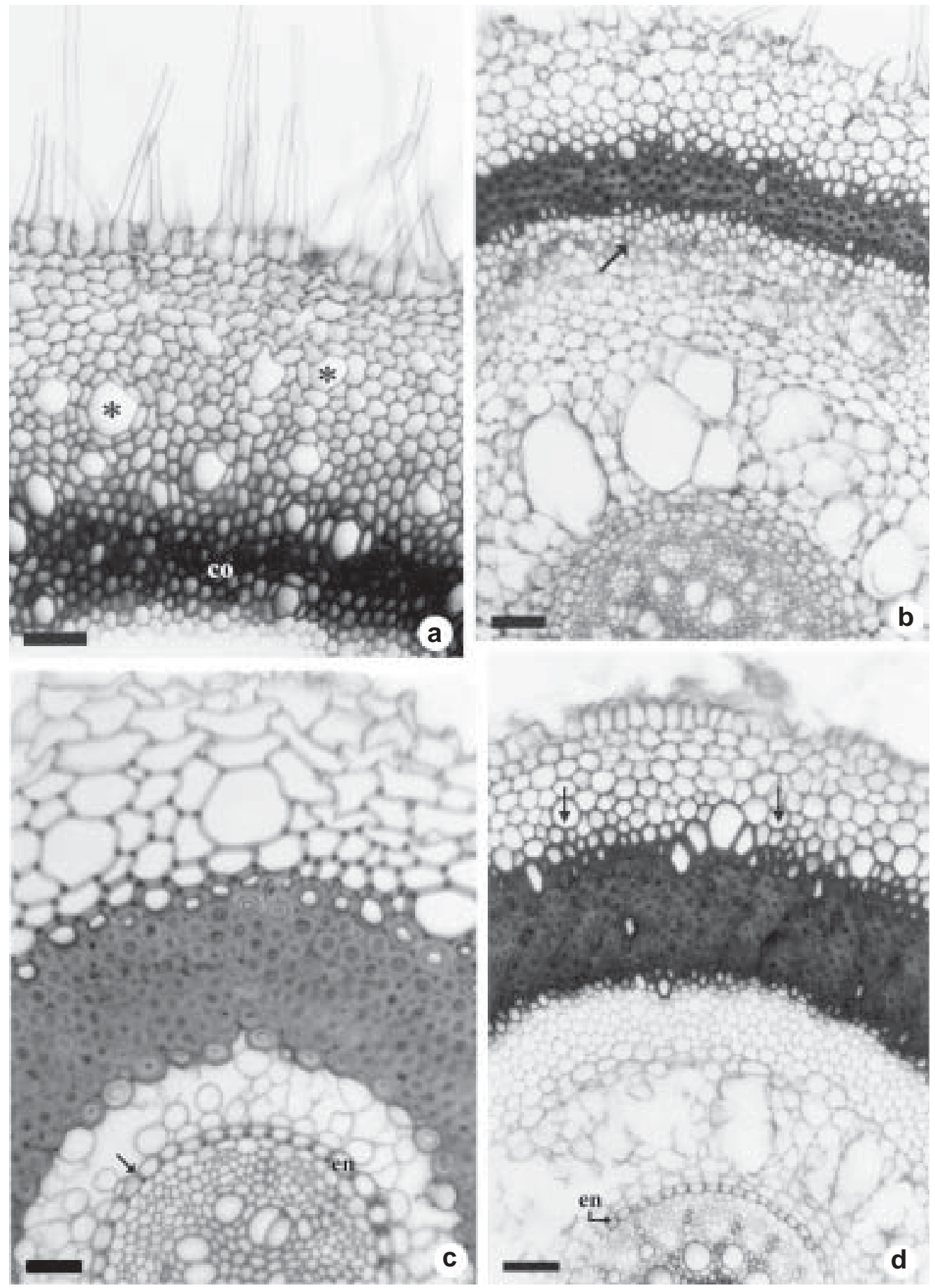

Figure 4-Cross sections at the median region of the roots. a. Bromelia balansae, with unicellular hairs on the epivelamen and idioblasts of raphides (asterisks) on the velamen layers; note the lignified cells on the outer cortex (co) and on the inner velamen. b. Aechmea bromeliifolia, with unicellular hairs on the epivelamen; note the centripetal sclerification of the outer cortex cells (arrow) and the wide intracellular spaces in the inner cortex. c. Billbergia distachia, with the cortex almost completely sclerified and the endoderm cells (en) with thickened anticlinal walls (arrow). d. Ananas ananassoides, with thick walled cells on the inner velamen (arrows) and endoderm cells with thickened anticlinal walls (en). Bars $=30 \mu \mathrm{m}$ (fig. c); $70 \mu \mathrm{m}$ (fig. a, b, d). 

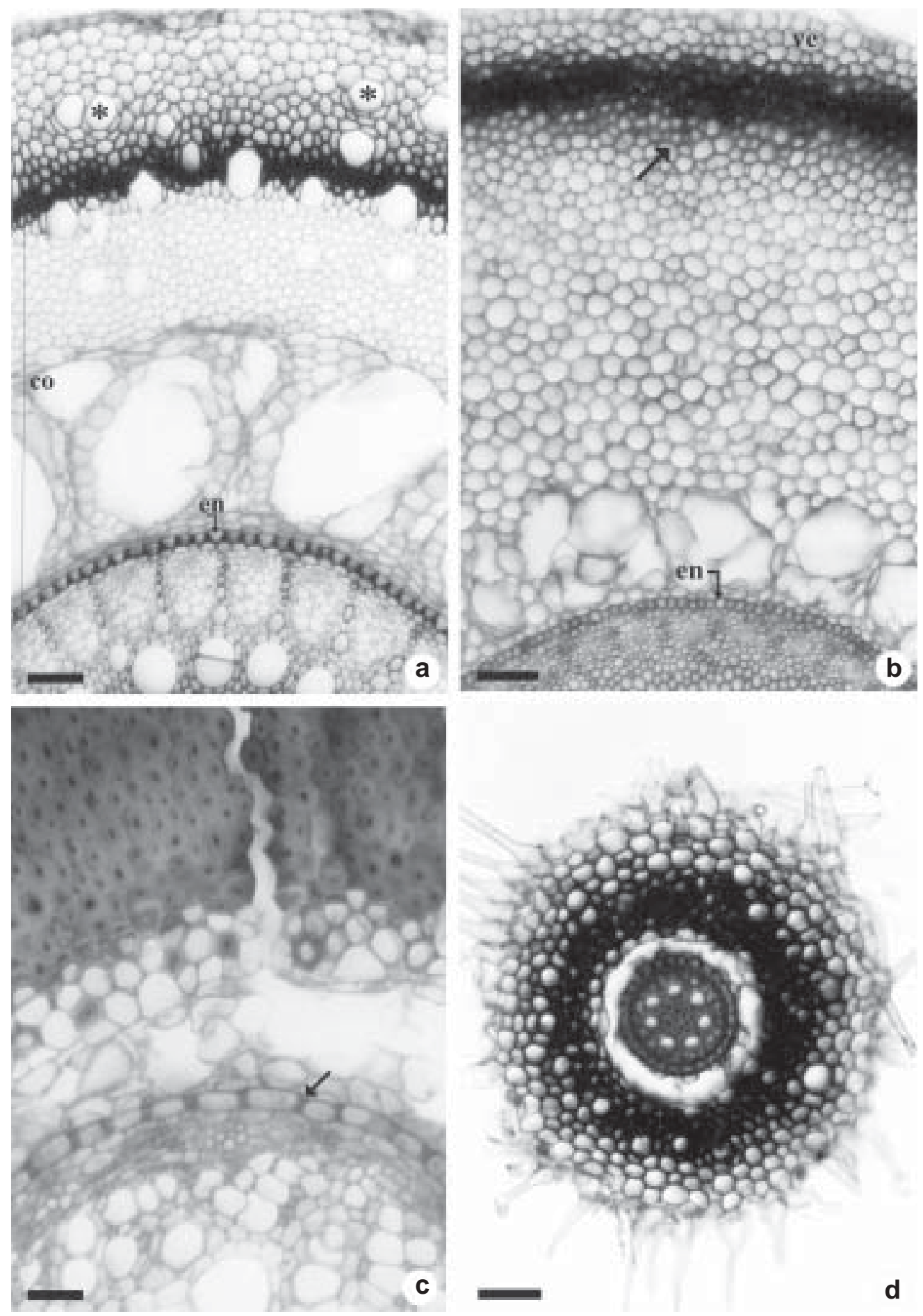

Figure 5 - Cross sections at the median region of the roots. a. Bromelia balansae, show idioblasts of raphides without content (asterisks) on the velamen that has thick walled cells on its inner layers; the outer cortex is sclerified and the inner cortex present wide intercellular spaces; the endoderm cells have thickened anticlinal and inner periclinal walls (en). b. Vriesea sp., showing the velamen (ve), the centripetal sclerification of the outer cortex cells (arrow) and the endoderm cells with thickened anticlinal and periclinal walls (en). c. Dyckia tuberosa, showing the cortex almost completely sclerified and the endoderm cells with thickened anticlinal walls (arrow). d. Bromelia balansae, lateral root with the same

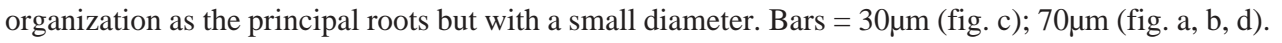



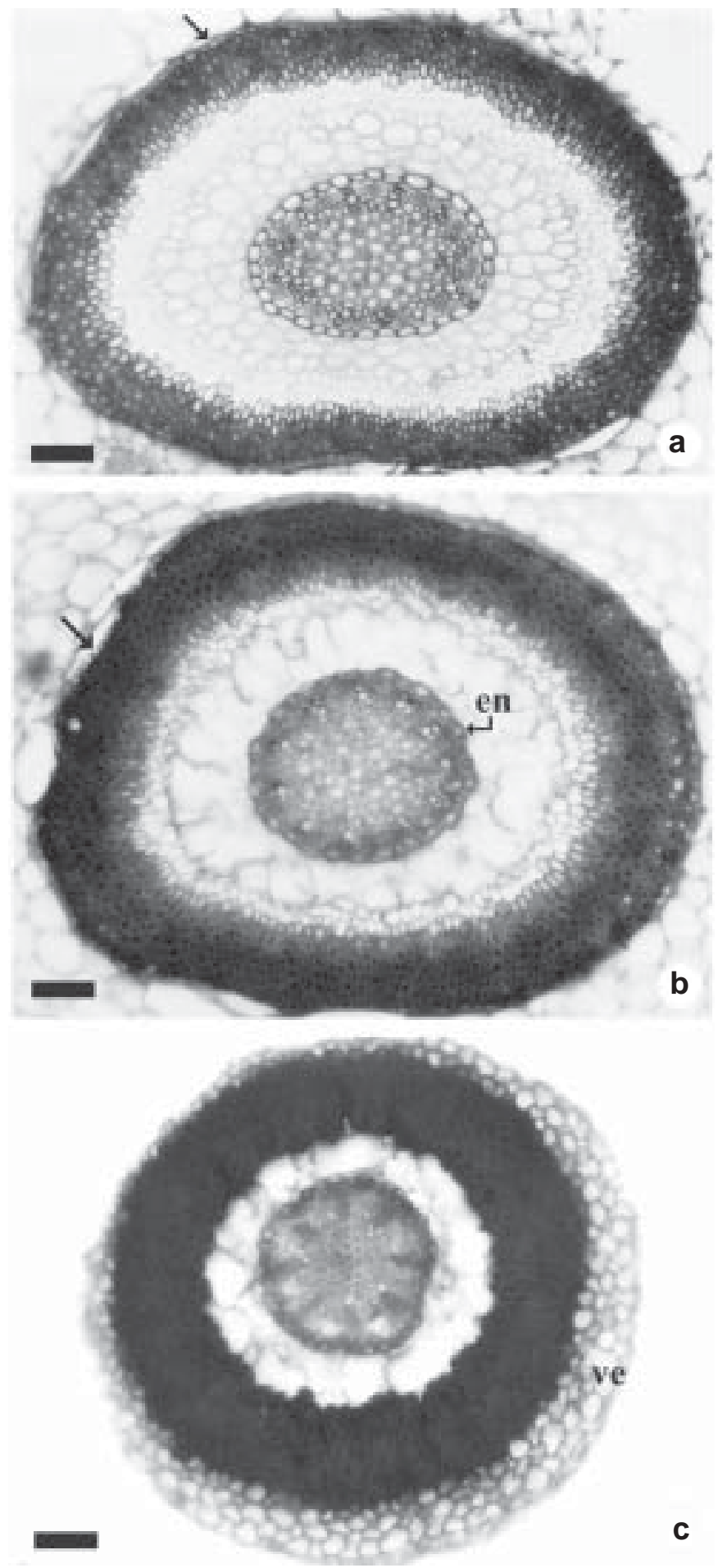

C

Figure 6 - Cross sections of the Tillandsia tenuifolia roots. a. intracortical portion near of the root apex with the onelayered epidermis (arrow), the outer cortex of thick walled cells and the inner cortex with stratified enlarged cells. b. intracortical portion at the median root region showing the one-layered epidermis (arrow), the centripetal sclerification of the outer cortex and the wide intercellular spaces on the inner cortex; the endoderm cells are thick walled (en) at this root region. c. aerial portion with a velamen (ve). Bars $=70 \mu \mathrm{m}$ (fig. $\mathrm{a}, \mathrm{b}, \mathrm{c}$ ). 


\section{Discussion}

The coating tissue of the rhizomes is multilayered and its cells present suberized walls, in all Bromelioideae, some Tillandsioideae (T. pohliana and T. tenuifolia) and in the Pitcairnioideae D. tuberosa. Tomlinson (1969) called this tissue periderm but no phellogen was observed in the rhizomes studied here. So we prefer to call the coating tissue stratified cork that, according to Fahn (1985), originates from some groups of cortical parenchymatous cells that divide periclinally forming many layers of cells with suberized walls.

All rhizomes have a cortex and a central cylinder that, in most species, is limited by a ring of lignified cells interpreted, in the present work, as the pericycle. In some rhizomes, the limit of the central cylinder presents vascular networks interrupted by the leaf gaps and associated to the adventitious roots, as described for Ananas comosus (L.) Merr. (Krauss 1948). In A. comosus, the vascular network originates from a meristem that Mangin (1882 apud Krauss 1948) called a dictiogen layer and Diggle \& DeMason (1983) named a primary thickening meristem, and which, according to Menezes et al. (2005), corresponds to the pericycle. The structural similarity between the rhizomes of $A$. comosus and those of the Bromeliaceae studied here indicates that the primary thickening meristem is active in the stems of this family, producing variable degrees of peripheral vascular networks, depending on the species. According to Rudall (1991), the primary thickening meristem is a plesiomorphy for the monocotyledons, occurring in reduced stems of different families within this group. As in other monocotyledons (DeMason 1979, 1980; Martin \& Tucker 1985; Rudall 1991; Scatena \& Menezes 1995; Sajo \& Rudall 1999), the rhizomes of the Bromeliaceae do not show any secondary growth, which is characterized by the formation of radially organized vascular bundles separated by parenchymatous rays, and an increase of parenchymatous cells in the cortex.
Inside the cortex there are intracortical roots in the rhizomes of Tillandsioideae (except for Tillandsia usneoides and Vriesea sp.) and of D. tuberosa (Pitcairnioideae), as described by Pita \& Menezes (2002) and by Segecin \& Scatena (2004) for others representatives of the same family. The intracortical roots observed here do not present a multilayered rhizodermis, as reported for others Tillandsia (Segecin \& Scatena, 2004) and contrary to described for Dyckia and Encholirium (Pita $\&$ Menezes 2002). Here, the intracortical roots are covered by one layer of rhizodermis that become sclerified in distal regions of the organ.

In both terrestrial and epiphytic species, the extracortical part of the roots is covered by a multilayered rhizodermis. This multilayered rhizodermis is morphologically similar to the velamen hat covers the roots of epiphytic and terrestrial species of Araceae and Orchidaceae (Dycus \& Knudson 1957, Benzing et al. 1982, Fahn 1985 and Mauseth 1988) and may function like it. In Araceae and Orchidaceae, the velamen offers mechanical protection and acts as a sponge, allowing the root to retain a temporary reservoir of water and minerals (Benzing et al. 1982). In Bromeliaceae, the occurrence of a multilayered rhizodermis (named velamen by the authors) was also reported for rupicolous species of Dyckia and Encholirium (see Pita \& Menezes 2002) and for epiphytic species of Tillandsia (Segecin \& Scatena 2004).

Internally to the multilayered rhizodermis, there is a one-layered exodermis formed by thick-walled cells, as described for other Bromeliaceae roots (Pita \& Menezes 2002, Segecin \& Scatena 2004). As in other roots (see Sanford \& Andalawo 1973, Pita \& Menezes 2002), some exodermis cells have only primary walls (passage cells) allowing the water solution to move from the multilayered rhizodermis to the cortex (Dycus \& Knudson 1957). According to Tomlinson (1969) and Dycus \& Knudson (1957), the velamenexodermis set of some epiphytic species offers a mechanical protection, reduces the water loss 
from the root cortex, and absorbs and stores water and minerals (Benzing et al. 1982). In the roots studied here, the multilayered rhizodermis-exodermis set could act like the velamen-exodermis set protecting the organ and absorbing/retaining the water and solutes. However, only detailed physiological and ecological studies could confirm this hypothesis.

The outer cortex of the root is formed by cells of sclerified walls and, in some cases, these sclerification reaches the cell walls of the median cortex. These multilayered tissue formed by sclerified cells probably helps to hinder the water evaporation from the inner root cortex, as suggested by Krauss (1949) for A. comosus roots. Collenchymatous cells were reported for the median cortex of the roots of Dyckia and of Encholirium (Pita \& Menezes 2002); however, none of the observed roots presented this supporting tissue.

The layers of the inner root cortex, adjacent to the endodermis, are stratified close to the root apex, indicating that the inner cortex originates from a meristematic endodermis, as demonstrated by Alonso et al. (2004) and by Menezes et al. (2005) for other monocotyledons.

On the mature region, the root endodermis is formed by thick-walled cells in Tillandsioideae and by cells with thickened anticlinal walls in Pitcairnioideae and most Bromelioideae (except for Bromelia balansae with U thickenings).

The medulla is parenchymatous in the root apex but its cell walls become thick and lignified in the distal regions including in the intracortical parts. Such sclerification probably increases the support for the epiphytic rhizomes as proposed by Meyer (1940 apud Tomlinson 1969).

The sclerified exodermis and medulla observed here may offer support for the roots during its growth within the stem, as proposed by Krauss (1949) for A. comosus. Such sclerified tissues can also increase the resistance of the roots against water loss, avoiding cellular collapse.
Crystals of calcium oxalate are common in the rhizomes and roots studied here, as reported for other Bromeliaceae (Krauss 1948, Tomlinson 1969, Segecin \& Scatena 2004). Such crystals, whose function would be to neutralize the oxalic acid produced in the plants (Brighigna et al. 1984), may either represent forms of reserve of calcium and of oxalic acid, reintroduced in the metabolism when necessary (Sunell \& Healey 1979), or deposits of metabolic wastes that would otherwise be toxic to the cell or tissue (Prychid \& Rudall, 1999). According to Mauseth (1988), Finley (1999) and Prychid \& Rudall (1999), the calcium oxalate raphides make the plants little palatable to herbivores. Within Poales, raphides of calcium oxalate occur in Eriocaulaceae, Joinvilleaceae, Sparganiaceae and Typhaceae (Dalhgren et al. 1985), suggesting that this feature is a plesiomorphy for the order. Although the presence/absence of crystals is of taxonomic value for some plant groups (Prychid \& Rudall 1999), the raphides of calcium oxalate are not a good feature for grouping/separating the Bromeliaceae, since they occur in a generalized way.

Silica bodies are frequent inside the epidermal cells of the rhizomes. Considering that these bodies are low palatability, they have been associated to the plant resistance against infestation of fungi and insects attacks (Balasta et al. 1989). Silica bodies are also found in other Poales, as Poaceae, Cyperaceae, Thurniaceae, Rapateaceae, Centrolepidaceae, Ecdeiocoleaceae and Joinvilleaceae (Prychid et al. 2004), indicating that this feature is a plesiomorphy for the order. In Bromeliaceae, the silica bodies are always spherical and restricted to the epidermis cells, corroborating the supposition of Prychid et al. (2004) for whom the form and localization of these crystals can have a systematic potential for some groups of monocotyledons.

Some structural features of the roots and rhizomes could act in the maintenance of the hydric balance allowing the plant to explore extreme habitats, such as rock surfaces and 
ephiphytic habitats. The occurrence of these features may also be related to the cerrado environment (where the studied species occur) where the dry season is up to 6 months (Ribeiro $\&$ Walter 1998) and the maximum vapour pressure deficits is similar in both rainy and dry season (Meinzer et al. 1999).

\section{ACKnowledgments}

We thank the Conselho Nacional de Desenvolvimento Científico e Tecnológico (CNPq) for a Doctoral fellowship (first author) and a Researcher fellowship (second author), and the Projeto Biota - Fundação de Amparo à Pesquisa do Estado de São Paulo (FAPESP) for the financial support.

\section{REFERENCES}

Alonso, A. A.; Moraes-Dallaqua, M. A. \& Menezes, N. L. 2004. Endoderme com atividade meristemática em raiz de Canna edulis Kerr-Gawler (Cannaceae). Acta Botanica Brasilica 18: 693-699.

APG (The Angiosperm Phylogeny Group). 2003. An update of the Angiosperm Phylogeny Group classification for the orders and families of flowering plants: APG II. Botanical Journal of the Linnean Society 141: 399-436.

Balasta, M. L. F. C.; Perez, C. M.; Juliano, B. O.; Villareal, C. P.; Lott, J. N. A. \& Roxas, D. B. 1989. Effects of silica level on some properties of Oryza sativa straw and hull. Canadian Journal of Botany 67: 2356-2363.

Benzing, D. H. 1973. The monocotyledons: their evolution and comparative biology. I Mineral nutrition and related phenomena in Bromeliaceae and Orchidaceae. The Quarterly Review of Biology 48: 277-290. 2000. Bromeliaceae: profile of an adaptative radiation. Cambridge University Press, Cambridge, 690p.

Benzing, D. H. \& Burt, K. M. 1970. Foliar permeability among twenty species of the Bromeliaceae. Bulletin of the Torrey Botanical Club 97: 269-279.
Benzing, D. H.; Ott, W. E \& Friedman, W. E. 1982. Roots of Sobralia macrantha (Orchidaceae): structure and function of the velamen-exodermis complex. American Journal of Botany 69: 608-614.

Benzing, D. H.; Henderson, K.; Kessel, B. \& Sulak, J. 1976. The absorptive capacities of bromeliad trichomes. American Journal of Botany 63: 1009-1014.

Billings, F. H. 1904. A study of Tillandsia usneoides. Botanical Gazette 38: 99-121.

Brighigna, L.; Fiordi, A. C. \& Palandri, M. R. 1984. Structural characteristics of mesophyll in some Tillandsia species. Phytomorphology 34: 191-200.

Chamberlain, C. J. 1932. Methods in plant histology. $5^{\text {th }}$ ed. University of Chicago Press, Chicago, 416p.

Crayn, D. M.; Randall, G. T.; Smith., J. A. C. \& Winter, K. 2000. Molecular systematics investigations in Pitcairnioideae (Bromeliaceae) as a basis for understanding the evolution of crassulacean acid metabolism (CAM). In: Winter, K. L. \& Morrison, D. A. (eds.). Monocots: systematic and evolution. CSIRO Publishing, Melbourne. Pp. 569-579.

Dahlgren, R. M. T.; Clifford, H. T. \& Yeo, P. F. 1985. The families of the monocotyledons. Structure, evolution, and taxonomy. $1^{\text {st }} \mathrm{ed}$. Springer-Verlag, Berlin, 520p.

DeMason, D. A. 1979. Function and development of the primary thickening meristem in the monocotyledon, Allium cepa L. Botanical Gazette 140: 51-66.

1980. Localization of cell division activity in the primary thickening meristem in Allium cepa. L. American Journal of Botany 67: 393-399.

Diggle, P. K. \& De Mason, D. A. 1983. The relationship between the primary thickening meristem and the secondary thickening meristem in Yucca Whipplei Torr. I. Histology of the mature vegetative stem. American Journal of Botany 70: 1195-1983. 
Dycus, A. M. \& Knudson, L. 1957. The role of the velamen of the aerial roots of orchids. Botanical Gazette 119: 78-87.

Fahn, A. 1985. Plant anatomy. $3^{\text {rd }}$ ed. Ediciones Pirámide, S.A., Madrid, 560p.

Finley, D. S. 1999. Patterns of calcium oxalate crystals in young tropical leaves: a possible role as an anti-herbivory defense. Revista de Biología Tropical 47: 27-31.

Gerlach, D. 1984. Botanische Mikrotechnik. Georg. Thieme Verlag, Stuttgart, 311p.

Horres, R.; Zizka, G.; Kahl, G. \& Weising, K. 2000. Molecular phylogenetics of Bromeliaceae: evidence from trnl (uaa) intron sequences of the chloroplast genome. Plant Biology 2: 306-315.

Johansen, D. A. 1940. Plant microtechnique. $3^{\text {rd }}$ ed. McGraw-Hill Book Company, New York, 523p.

Kaiser, E. 1880. Verfahren zur Herstellung einer tadellosen glycerin-gelatine. Botanisch Zentralb 180: 25-26.

Kraus, J. E. \& Arduin, M. 1997. Manual básico de métodos em morfologia vegetal. EDUR, Seropédica, 198p.

Krauss, B. H. 1948. Anatomy of the vegetative organs of the Pineapple, Ananas comosus (L.) Merr. I - Introduction, organography, the stem, and the lateral branch or axillary buds. Botanical Gazette 110: 159-217.

1949. Anatomy of the vegetative organs of the Pineapple, Ananas comosus (L.) Merr. III - The root and the cork. Botanical Gazette 110: 550-587.

Luther, H. E. 2002. An alphabetical list of bromeliad binomials. $8^{\text {th }}$ ed. Bromeliad Society International, Sarasota.

Martin, B. F. \& Tucker, S. C. 1985. Developmental studies in Smilax (Liliaceae). I. Organography and the shoot apex. American Journal of Botany 72: 66-74.

Mauseth, J. D. 1988. Planty anatomy. The Benjamin/Cummings Publishing Company, California, 560p.

Meinzer, F. C.; Goldstein, G.; Franco, A. C.; Bustamante, M.; Igler, E.; Jackson, P.; Caldas, L. \& Rundel, P. W. 1999.
Atmospheric and hydraulic limitations on transpiration in brazilian cerrado woody species. Functional Ecology 13: 273-282.

Menezes, N. L.; Silva, D. C.; Arruda, R. C. O.; Melo-de-Pinna, G. F.; Cardoso, V. A.; Castro, N. M.; Scatena, V. L.; Scremin-Dias, E. 2005. Meristematic activity of the endodermis and the pericycle in the primary thickening in monocotyledons. Considerations on the "PTM". Anais da Academia Brasileira de Ciências 77: 259-274.

Pita, P. B. \& Menezes, N. L. 2002. Anatomia da raiz de espécies de Dyckia Schult. \& Schult. f. (Bromeliaceae, Pitcairnioideae) da Serra do Cipó (Minas Gerais, Brasil), com especial referência ao velame. Revista Brasileira de Botânica 25: 25-34.

Pittendrigh, C. S. 1948. The bromeliadAnopheles-malaria complex in Trinidad. I. The bromeliad flora. Evolution 2: 58-89.

Prychid, C. J. \& Rudall, P. J. 1999. Calcium oxalate crystals in monocotyledons: a review of their structure and systematics. Annals of Botany 84: 725-739.

Prychid, C. J.; Rudall, P. J. \& Gregory, M. 2004. Systematics and biology of silica bodies in monocotyledons. Botanical Review 69: 377-440.

Ribeiro, J. F. \& Walter, B. M. T. 1998. Fitofisionomias do bioma cerrado. In: Sano, S. M. \& Almeida, S. P. (coords.). Cerrado: ambiente e flora. EMBRAPACPAC, Planaltina. Pp.89-166.

Rudall, P. J. 1991. Lateral meristems and stem thickening growth in monocotyledons. Botanical Review 57: 150-163.

Sajo, M. G. \& Rudall, P. J. 1999. Systematic vegetative anatomy and ensiform leaf development in Xyris (Xyridaceae). Botanical Journal of the Linnean Society 130: 171-182.

Sanford, W. W. \& Adanlawo, I. 1973. Velamen and exodermis characters of West African orchids in relation to taxonomic grouping and habitat tolerance. Botanical Journal of the Linnean Society 66: 307-321. 
Sass, J. E. 1951. Botanical microtechnique. $2^{\text {nd }}$ ed. Iowa State College Press, Iowa, 228p.

Scatena, V. L. \& Menezes, N. L. 1995. Aspectos morfológicos e anatômicos do caule em espécies de Syngonanthus Ruhl. Eriocaulaceae. Boletim Botânico da Universidade de São Paulo 14: 91-107.

Segecin, S. \& Scatena, V. L. 2004. Morfoanatomia de rizomas e raízes de Tillandsia L. (Bromeliaceae) dos Campos Gerais, PR, Brasil. Acta Botanica Brasilica 18: 253-260.

Smith, L. B. \& Downs, R. J. 1974. Pitcairnioideae (Bromeliaceae). Flora Neotropica. Monograph 14: 1-662.
.1977. Tillandsioideae (Bromeliaceae). Flora Neotropica. Monograph 14: 663-1492. 1979. Bromelioideae (Bromeliaceae). Flora Neotropica. Monograph 14: 14932142.

Sunell, L. A. \& Healey, P. L. 1979. Distribution of calcium oxalate crystal idioblasts in corms of taro (Colocasia esculenta). America Journal of Botany 66: 1029-1032.

Tomlinson, P. B. 1969. Comelinales Zingiberales. In: Metcalfe, C. R. (ed.). Anatomy of the monocotyledons. Vol. 3. Oxford University Press, London. Pp. 193-294. 